УДК 371.134

DOI: $10.15330 /$ esu.1.67-75

\section{Дмитро Іщценко,}

доктор педагогічних наук, професор,

заслужений працівник освіти України, Національна академія Державної прикордонної службо України ім. Б. Хмельницького (м. Хмельницький, Україна)

Dmytro Ishchenko,

Doctor of Pedagogical Sciences, Professor, Honored Worker of Education of Ukraine, National Academy of the State Border Guard Service of Ukraine

(Khmelnitsky, Ukraine)

dischenko1955@ukr.net

\section{Юлія Адамчук,}

ад'юнкт, Національна академія Державної прикордонної служби України м. Б. Хмельницького (м. Хмельницький, Україна)

Yuliia Adamchuk, post-graduate student, National Academy of the State Border Guard Service of Ukraine (Khmelnitsky, Ukraine) ginger_2004@ukr.net

\title{
ФОРМУВАННЯ ФУНКЦІОНАЛЬНИХ КОМПЕТЕНЦЙ МОЛОДШОГО ПЕРСОНАЛУ ДЕРЖАВНОЇ ПРИКОРДОННОЇ СЛУЖБИ УКРАЇНИ
}

\section{FORMING OF FUNCTIONAL COMPETENCIES OF JUNIOR STAFF OF THE STATE BORDER GUARD SERVICE OF UKRAINE}

У статті наведена характеристика та опис особливостей формувания функиіональних компетенцій молодиого персоналу Державної прикордонної служби України (ДПСУ) у прочесі базової підготовки та підвищення кваліфікачії в ході навчання у Головному центрі підготовки персоналу ДПСУ. Відповідні компетениії включають в себе базові компетениії, необхідні для усъого масиву молодиого персоналу прикордонної служби та додаткові функиіональні компетениії, які необхідні для виконання обов 'язків на кожній окремій посаді. Майбутній перелік функціональних компетениій містить їх визначення для кожной посади ДПСУ. Оскільки вони становлять основу для просувани по службі, вони мають бути взаємопов'язаними таким чином, щоб очінка забезпечувала бачення наскільки прикордонник буде відповідати компетенціям на іниій рівнозначній або на вищій посаді.

Ключові слова: компетентність, компетенціi, функиіональні компетенції, молодиий персонал.

The article describes the characteristics and description of the peculiarities of functional competencies formation of junior staff of the State Border Guard Service of Ukraine (SBGSU) in the process of basic and advanced training during education at the Main Training Center of SBGSU staff. Relevant competencies include the basic competencies required for the all staff of junior border guards and the additional functional competencies required to perform the duties in each individual position. The future list of functional competencies includes their definition for each SBGSU position. As they form the basis for promotion, they must be interconnected in such a way that the assessment provides a vision of how well the border guarder will meet the competences in another equivalent or senior position.

It can be argued that a competent approach in the training of SBGSU junior staff provides the necessary level of readiness to perform duties in the units of state border protection. Functional competencies are formed and improved throughout the professional life of a serviceman. The functional competencies formation of the SBGSU junior staff, occurs during a specific educational process at the Main Center of Personnel Training of the SBGSU in the 
process of studying the cycle of general and military-special educational disciplines, as well as during extracurricular time under the guidance of teachers and commanders in specific specialties. For the formation of functional competences of the SBGSU junior staff in the process of training in the specialties, it is important to determine the content of training in each discipline (in particular, in the cycle of military and special subjects), taking into account the description of these competencies, features of their formation and indicators to evaluate each border guarder within every such competence, based on principles of expediency, science and systematicity.

Key words: competence, competencies, functional competencies, junior staff.

Постановка проблеми в загальному вигляді та ії зв'язок з важливими науковими і практичними завданнями. Державна прикордонна служба України (ДПСУ) досягла значних успіхів у впровадженні нових моделей підготовки та проходження служби персоналом підрозділів охорони державного кордону. Постійно відбувається активний пошук нових форм та способів підготовки, вивчається та втілюється найкращий світовий та європейський досвід

Зокрема, упровадження компетентнісного підходу у практику підготовки та підвищення кваліфікації прикордонників є одним із основних завдань професійної освіти, яке пов'язане $з$ необхідністю формування майбутнього фахівця, який зможе швидко адаптувалися до складних та динамічних умов оперативно-службової діяльності прикордонних підрозділів, реагувати на виклики часу, орієнтуватись у сучасному суспільстві та бути конкурентоспроможним на ринку праці. На думку сучасних педагогів, саме набуття життєво важливих компетентностей, у тому числі й у сфері професійної діяльності, дає людині можливості легко пристосовуватися до мінливих умов сьогодення.

Аналіз останніх досліджень і публікацій, в яких започатковане вирішення даної проблеми i на які спирається автор. Досвід світових та європейських правоохоронних органів свідчить про те, що компетенції $є$ комплексом характеристик працівника, які включають як знання і навички, так і особистісні характеристики: природжені здібності, емоційні особливості і вольові установки, що виявляються в діловій поведінці [1].

Останніми роками, питанням упровадження компетентнісного підходу у систему професійної освіти прикордонників присвячені наукові дослідження Г. Артюшина, О. Діденка, С. Сисоєвої, О. Ставицького, О. Торічного та інших. Приміром, вони розглядають особливості змісту та сутність професійної компетентності офіцера-прикордонника $[2$, с. 263, 264], вивчають формування професійної компетентності майбутніх офіцерів-прикордонників засобами проектної діяльності [9] тощо.

На думку основоположників компетентнісного підходу, професійна компетентність передбачає усвідомлення особистісних потягів до діяльності, потреб та інтересів; прагнення і ціннісні орієнтації; мотиви діяльності; уявлення про свої соціальні ролі; професійні знання, уміння і навички, професійно важливі якості [4; 10$]$.

Заслуговує на увагу науковий підхід науковців С. Сисоєвої та I. Соколової, які зазначають, що професійна компетентність передбачає: усвідомлення особистісних потягів до діяльності, потреб та інтересів; прагнення і ціннісні орієнтації мотиви діяльності; уявлення про свої соціальні ролі; самооцінку особистісних властивостей і якостей; професійних знань, умінь i навичок, професійно важливих якостей; регулювання свого професійного становлення. Отже, професійна компетентність фахівця $\epsilon$ інтегративною властивістю особистості, що визначає здатність фахівця здійснювати професійну діяльність на найвищому рівні [7, с. 156]. 
Досліджуючи проблему формування військово-спеціальної компетентності майбутніх прикордонників у процесі навчання, О. Торічний зауважує, що професійна підготовка майбутніх прикордонників, на противагу професійної підготовки фахівців у цивільних закладах освіти, має специфічні особливості, зумовлені характером і специфікою їхньої майбутньої професійної діяльності $[8$, с. 91]. У цьому контексті Е. Сарафанюк зазначає, що об'єктом навчально-виховного впливу $\epsilon$ курсанти, що пройшли військово-професійний відбір; навчальна діяльність $€$ основним службовим обов'язком курсантів; зміст, форми, методи і засоби іiі реалізації визначаються науково-технічним прогресом у військовій галузі [6, с. 11]. Отже, рівень сформованості його фахових компетенцій багато в чому визначатиме результат усієї діяльності.

Виокремлення невирішених раніше аспектів загальної проблеми, які суголосні із статтею. Теоретичний аналіз наукових праць, в яких представлено результати проведених досліджень, показав, що проблема формування функціональних компетенцій молодшого персоналу Державної прикордонної служби, які визначають готовність молодших інспекторів прикордонної служби до оперативнослужбової діяльності на державному кордоні недостатньо досліджена й розроблена у теоретичному і практичному аспектах.

Метою статті $є$ визначення та опис особливостей формування функціональних компетенцій молодшого персоналу дпсу у процесі базової підготовки та підвищення кваліфікації у головному центрі підготовки персоналу державної прикордонної служби україни.

Виклад основного матеріалу дослідження 3 повним обгрунтуванням отриманих результатів. Очевидним $є$ те, що для молодшого персоналу ДПСУ важливо володіти фаховими компетенціями, які визначають їх здатність виконувати завдання, що визначені посадовою інструкцією. Так, відповідно до посадової інструкції молодшого інспектора прикордонного контролю до основних завдань входить: твердо знати і правильно застосовувати законодавство України; у повному обсязі знати договірно-правові документи і міжурядові угоди України, що регламентують пропуск через державний кордон осіб; точно виконувати вимоги законів та інших нормативно-правових актів України, а також розпорядчих актів Адміністрації Держприкордонслужби, що регламентують організацію та здійснення охорони державного кордону; постійно відслідковувати та знати обстановку, негайно доповідати і вчасно реагувати на їі зміни; особисто брати участь в охороні державного кордону, прикордонному контролі; вміти організовувати службу 3 прикордонних питань всіма прикордонними нарядами із складу зміни прикордонних нарядів та складати необхідні оперативно-службові документи за результатами служби; здійснювати протидію правопорушенням, які законодавством віднесено до компетенції Держприкордонслужби; в ході несення служби виявляти та затримувати порушників законодавства 3 прикордонних питань; постійно удосконалювати свою фахову підготовку; здійснювати профілювання ризиків на ділянці відповідальності. [3].

Посадові обов'язки, які містяться в посадовій інструкції, передбачають наявність відповідного рівня функціональних компетенцій.

Відповідні компетенції молодшого персоналу ДПСУ включають в себе базові компетенції, необхідні для усього масиву прикордонної служби та додаткові функціональні компетенції, які необхідні для якісного виконання обов'язків на кожній окремій посаді. 
Перелік функціональних компетенцій складається для кожної посади ДПСУ. Оскільки вони становлять основу для просування по службі, вони мають бути взаємопов'язаними таким чином, щоб оцінка забезпечувала бачення наскільки прикордонник буде відповідати компетенщіям на іншій рівнозначній або на вищій посаді. Ці взаємозв'язки реалізовано шляхом визначення споріднених посад.

Функціональні компетенції - це набір 4-5 додаткових компетенцій, які відповідають ключовим видам діяльності на конкретній посаді.

Для молодшого інспектора прикордонного контролю визначено наступні функціональні компетенції: перевірка документів; огляд транспортних засобів і вантажів; взаємодія та співпраця 3 питань прикордонного контролю та контроль режиму пункту пропуску.

Перевірка документів - дослідження прикордонником паспортного та іншого документів фізичних осіб (громадян), які перетинають державний кордон, 3 метою встановлення їх дійсності та приналежності відповідній особі (громадянину), а також дослідження за результатами оцінки ризиків документів, що стосуються транспортних засобів, вантажів.

Ця функціональна компетенція включає в себе дослідження документів, встановлення приналежності та оцінку ризиків.

Індикаторами для оцінки службової діяльності прикордонника в рамках цієї компетенції $€$ те, що він знає види підробок, які використовуються в паспортних документах та їх ознаки і виявляє їx; знає порядок реєстрації іноземців та їх паспортних документів; вміє зареєструвати іноземця та його паспортний документ; на основі оцінки ризиків безпосередньо виявляє в потоці осіб ознаки протиправної діяльності та вживає практичні заходи з протидії їм; керується положеннями технологічних схем пропуску через державний кордон осіб; вміє та оформляє службові та адміністративно-процесуальні документи на порушників які використовують підроблені документи; вміс досліджувати, встановлювати зразок документу, його національну приналежність та належність пред'явникові; знає опис та елементи захисту паспортних документів країн, що межують з Україною, та загальний опис i елементи захисту паспортних документів країн світу; встановлює іх приналежність; знає порядок перевірки документів які надають право перетинання державного кордону, порядок поставлення службових відміток ДПСУ.

Огляд транспортних засобів $і$ вантажів - комплекс дій та заходів, які здійснюе прикордонник щодо недопущення випадків незаконного переміщення через державний кордон осіб з використанням обладнаних схованок, через державний кордон зброї, наркотичних засобів, психотропних речовин і прекурсорів, боєприпасів, вибухових речовин, матеріалів і предметів, заборонених для переміщення через державний кордон, виявлення викрадених транспортних засобів. ризиків.

Ця функціональна компетенція включає в себе огляд, виявлення, оцінку

Індикаторами для оцінки службової діяльності прикордонника в рамках цієї компетенції $\epsilon$ те, що він знає порядок огляду та конструктивні особливості транспортних засобів закордонного прямування, місця можливого облаштування тайників та схованок; керується оцінкою ризиків при здійснені порядку контролю транспортних засобів, які перетинають державний кордон України; вміє виявляти місця облаштування схованок та тайників, викраденого автотранспорту; керується оцінкою ризиків щодо виявлення викраденого автомототранспорту; вміє та використовує технічні засоби та спеціальну техніку прикордонного контролю для 
огляду транспортних засобів, виявлення заборонених для переміщення вантажів; вміє з використанням оцінки ризиків безпосередньо виявляти в потоці транспортних засобів та вантажів ознаки протиправної діяльності та вживати практичні заходи 3 протидії їм; знає і виконує положення технологічних схем пропуску через державний кордон транспортних засобів, вантажів та іншого майна; вміє оглядати транспортні засоби закордонного прямування та вантаж, що прямують через державний кордоні.

Взасмодія та співпраця з питань прикордонного контролю - спосіб забезпечення прикордонного контролю, який полягає у спільній діяльності контрольних органів і служб, спрямованій на здійснення пропуску через державний кордон осіб, транспортних засобів та вантажів у межах їх компетенції.

Ця компетенція включає в себе спільний прикордонно-митний контроль, взаємодію 3 контролюючими органами, спільний контроль із суміжними державами.

Індикаторами для оцінки службової діяльності прикордонника в рамках цієї компетенції $\epsilon$ те, що він виконує порядок обміну інформацією про можливі правопорушення під час здійснення прикордонного та митного контролю; виконує проведення спільних контрольних заходів із відповідними структурними підрозділами прикордонної охорони щодо припинення порушення законодавства 3 прикордонних питань; здійснює проведення звірок про кількість автомобільного транспорту, який піддавався прикордонному та митному контролю; знає і керується порядком взаємодії у разі виявлення зброї, вибухівки та інших небезпечних предметів у пункті пропуску; знає і виконує порядок дій у разі виявлення порушень під час перевезення радіоактивних та небезпечних вантажів; знає і виконує порядок взаємодії прикордонних нарядів 3 контрольними органами i службами у пункту пропуску, їх залучення до контролю та послідовність проведення всіх видів контролю; знає і керується правилами обміну інформацією, підтриманням взаємодії 3 контролюючими службами у відповідності до вимого технологічної схеми; знає порядок обміну інформацією при проведені спільного контролю 3 відповідними структурними підрозділами прикордонної охорони інших держав.

Контроль режиму в пунктах пропуску - забезпечення порядку перебування і пересування всіх осіб і транспортних засобів у межах території прикордонних, залізничних і автомобільних станцій, морських і річкових портів, аеропортів і аеродромів, відкритих для міжнародного сполучення, а також здійснення іншої діяльності, пов'язаної з пропуском через державний кордон осіб, транспортних засобів та вантажів, який встановлюється наказом начальника органу охорони державного кордону, погодженим 3 начальником митного органу та керівником підприємства, на території якого розміщено пункт пропуску через державний кордон.

Ця компетенція включає в себе порядок доступу осіб i ̈̈х перебування в пунктах пропуску, рух транспортних засобів, перебування представників суміжних служб.

Індикаторами для оцінки службової діяльності прикордонника в рамках цієї компетенції $\epsilon$ те, що він знає порядок та здійснює пропуск представників правоохоронних органів, контрольних служб та підприємств на територію пункту пропуску; затримує та складає протоколи про адміністративне порушення на порушників режиму у пункті пропуску; здійснює контроль за виконанням правил перебування у пункті пропуску особам, та транспортним засобам; при проведенні спільного із суміжними державами прикордонного контролю, режим у пунктах пропуску підтримує відповідно до законодавства держави, на території якої він 
здійснюється; контролює дотримання режиму в зоні прикордонного контролю та запобігає проникненню сторонні осіб; регулює рух транспортних засобів у відповідності до наказів старших начальників; контролює додержання громадського порядку в пунктах пропуску; підтримує режим у пункті пропуску у відповідності до наказів старших начальників.

В процесі базової підготовки у Головному центрі підготовки персоналу Державної прикордонної служби України курсанти повинні набути необхідних знань та навичок для виконання обов'язків відповідно до майбутньої посади.

Основним принципом підготовки молодшого персоналу ДПСУ є поєднання загально-освітньої та професійної підготовки курсантів до майбутньої служби 3 охорони державного кордону. Але провідна роль в процесі підготовки належить дисциплінам, на вивчення яких відводиться більша кількість часу. До них належать як загальновійськові дисципліни (Статути 3С України, Загальновійськова тактика, Інженерна підготовка), так і військово-спеціальні дисципліни (Тактика прикордонної служби, Прикордонний контроль).

Згідно 3 Робочою навчальною програмою підготовки молодших інспекторів прикордонної служби, після закінчення навчання військовослужбовець повинен мати певний рівень базових знань, необхідних для подальшого проходження навчання відповідно до обраної спеціальності; вміти самостійно визначати форми та способи діяльності під час виконання службових обов'язків відповідно до чинного законодавства та функціональних обов'язків; виконувати завдання 3 охорони державного кордону, протидіяти протиправній та злочинній діяльності; рішуче протидіяти будь-яким провокаціям до корупційних діянь; при виникненні нестандартних ситуацій під час контролю осіб, транспортних засобів та вантажів спрямовувати свою діяльність відповідно до чинного законодавства. [5].

В результаті вивчення навчальної дисципліни "Статути Збройних Сил України" курсанти, відповідно до робочої навчальної програми цієї дисципліни, повинні ознайомитись із загальними обов'язками, правами та відповідальністю військовослужбовців та молодших командирів (загальні обов'язки командирів (начальників); відповідальність військовослужбовців; порядок віддання та виконання наказів); обов'язками посадових осіб добового наряду (підготовка добового наряду; обов'язки військовослужбовців добового наряду); порядком оголошення заохочень та накладання дисциплінарних стягнень (заохочення, які застосовують до рядових (матросів), сержантів (старшин); права командирів (начальників) щодо застосування до підлеглих; дисциплінарні стягнення, які накладаються на рядових (матросів), сержантів (старшин); права командирів (начальників) накладати дисциплінарні стягнення на підлеглих).

В результаті вивчення навчальної дисципліни "Загальновійськова тактика" курсанти, відповідно до робочої навчальної програми цієї дисципліни, повинні ознайомитись із основами тактики; базовими тактичними вправами (індивідуальні тактичні вправи; способи індивідуального пересування; індивідуальна вогнева позиція; вправи в складі малих тактичних груп; рух двійками, трійками, четвірками; рух в колоні); основами топографії (загальні відомості з топографії; топографічні карти; системи координат; робота 3 картою; рух за азимутом; орієнтування на місцевості; рух за визначеним азимутом); бойовим наказом (бойове завдання та складові бойового наказу; бойовий наказ на оборону, наступ, несення служби на блок-посту). 
Метою вивчення дисципліни "Інженерна підготовка" $\epsilon$ теоретична та практична підготовка військовослужбовця ДПС України за наступними напрямками: інженерне облаштування та маскування позицій прикордонного підрозділу (порядок інженерного облаштування позицій; порядок маскування позицій); інженерно-технічні засоби охорони державного кордону; загальна будова, можливості тепловізійних, електронно-оптичних комплексів та приладів, порядок їх використання в охороні кордону, ведення спостереження за допомогою тепловізійних приладів; вибухові речовини та засоби підриву; заходи безпеки при поводженні 3 вибухонебезпечними предметами; протипіхотні та протитанкові міни, саморобні вибухові пристрої, порядок дій особового складу при виявленні вибухонебезпечних предметів.

В основу підготовки молодших інспекторів прикордонного контролю покладено блок військово-спеціальних дисциплін: “Тактика прикордонної служби”, "Прикордонний контроль" тощо.

В результаті вивчення навчальної дисципліни "Тактика прикордонної служби" курсанти, відповідно до робочої навчальної програми цієї дисципліни, повинні ознайомитись із загальними положеннями з охорони державного кордону України (Державний кордон та його визначення, встановлення державного кордону та його позначення; режим державного кордону та прикордонний режим, загальні положення про територіальне море та внутрішні води України; загальна структура, призначення та завдання ДПСУ; основи охорони державного кордону прикордонними підрозділами; форми оперативно-службової діяльності прикордонних підрозділів, прикордонні підрозділи, що здійснюють безпосередню охорону ДКУ, їх типи, категорії та завдання); службою прикордонних нарядів з охорони державного кордону (основи служби прикордонних нарядів; прикордонні наряди, їх види та обов'язки, основні способи несення служби прикордонними нарядами; підготовка прикордонних нарядів до служби; взаємодія та маскування прикордонних нарядів; застосування зброї прикордонними нарядами під час охорони державного кордону; застосування заходів фізичного впливу, спеціальних засобів прикордонними нарядами під час охорони державного кордону; служба прикордонних нарядів “Черговий підрозділу охорони кордону" та "Помічник чергового підрозділу охорони кордону"; служба прикордонного наряду "Прикордонний патруль"; служба прикордонних нарядів "Пост технічного спостереження" та "Пост спостереження"; служба прикордонного наряду "Контрольний пост"; орієнтування на місцевості без карти); прикордонним слідознавством (загальні положення прикордонного слідознавства, загальні поняття про утворення слідів людини; сліди та правила їх розпізнавання); практикою в організації та несенні служби у прикордонних нарядах (організація служби прикордонним нарядом; взаємодія та маскування прикордонних нарядів; опитування та перевірка документів, як способи несення прикордонної служби; дії прикордонного наряду під час виявлення ознак порушення державного кордону, пошук, переслідування та затримання порушників законодавства України з прикордонних питань; практика в організації та несенні служби в прикордонному наряді “Контрольний пост”, “Пост спостереження".

Під час практичних занять та в позанавчальний час у повсякденному житті у майбутніх прикордонників на основі отриманих знань та набутих умінь та навичок формуються відповідні компетенції. Зі “Стройової підготовки” на практичні заняття відводиться 10 годин із 12 годин (2 години аудиторних). Із “Загальновійськової тактики" на практичні заняття відводиться 28 годин iз 40 годин (8 годин аудиторних). 
Щодо навчальної дисципліни "Інженерна підготовка", то на практичні заняття відводиться 6 годин із 18 годин (10 годин аудиторних). Iз “Тактики прикордонної служби" на практичні заняття відводиться 30 годин із 78 годин (42 години аудиторних).

Висновки представленого у статті дослідження і перспективи подальших наукових розвідок із зазначеного напряму. Таким чином, можливо стверджувати, що компетентнісний підхід в процесі підготовки молодшого персоналу ДПСУ забезпечує необхідний рівень готовності до виконання службових обов'язків в підрозділах охорони державного кордону. Функціональні компетенції формуються та вдосконалюються протягом усього професійного життя військовослужбовця. Формування функціональних компетентностей молодшого персоналу ДПСУ, відбувається в ході специфічного навчального процесу у Головному центрі підготовки персоналу ДПСУ під час вивчення циклу загальновійськових та військовоспеціальних навчальних дисциплін, а також у позааудиторний час під керівництвом викладачів та командирів за визначеними спеціальностями. Для формування функціональних компетентностей у молодшого персоналу ДПСУ у процесі підготовки за спеціальностями важливим $\epsilon$ визначення змісту навчання 3 кожної навчальної дисципліни (зокрема дисциплін з циклу загальновійськових та військовоспеціальних) з урахуванням опису цих компетентностей, особливостей їх формування та індикаторів для оцінки прикордонника в рамках кожної такої компетентності, на основі принципів доцільності, науковості та системності.

\section{Література}

1. Аналітичний звіт про виконання 1 - го етапу впровадження кадрової компоненти в рамках проекту міжнародної технічної допомоги "Інноваційний підхід до кар'єрного росту" ("ІНКА"); за ред. Г. Шрома. / Г. Шром. - Київ, 2013. - 108 с.

2. Діденко О. В. Професійна компетентність офіцера-прикордонника: сутність поняття Освітньо-наукове забезпечення діяьністі правоохоронних органів і військових формувань України : тези VIII Всеукраїнської науково-практичної конференції / О.В.Діденко. Хмельницький: Вид-во НАДПСУ, 2015. - 636 с.

3. Організаційно-методичні рекомендації щодо організації оперативно-службової діяльності відділень інспекторів прикордонної служби : затв. Першим заступником Голови Держ прикрдон. служби України. - Київ, 18 січ. 2018 р.

4. Равен Д. Компетентность в современном обществе. Выявление, развитие и реализация / Д. Равен. - Москва: Когито-Центр, 2002. - 396 с.

5. Робоча навчальна програма підготовки за спеціальністю "Молодший інспектор прикордонної служби" в рамках проекту "Нове обличчя кордону". - Черкаси, 2018. - 83 с.

6. Сарафанюк Е. І. Педагогічні умови підвищення якості загальновійськової підготовки курсантів вищих військових навчальних закладів з використанням віртуального моделювання: автореф. дис. на здобуття наук. ступеня канд. пед. наук: 13.00.04 / Е. І. Сарафанюк. - Одеса, 2005. - 22 c.

7. Сисоєва С. О., Соколова І. В. Проблеми непереривної професійної осіти: тезариус наукового дослідження / С. О. Сисоєва, І. В. Соколова // наук. Видання НАПН України, Ін-т пед. освіти і освіти дорослих, МОН, Маріупольський держ. Гуманітарний ун-т. - Київ: Видавничий Дім "ЕКМО", 2010. - 362 c.

8. Торічний О. В. Теорія і практика формування військово-спеціальної компетентності майбутніх офіцерів-прикордонників у процесі навчання: монографія / О. В. Торічний. - Хмельницький: Вид-во НАДПСУ, 2012. - $536 \mathrm{c.}$

9. Торічний О. В. Формування професійної компетентності майбутніх офіцерів-прикордонників засобами проектної діяльності / О.В.Торічний. - Хмельницький: Вісник Національної академії Державної прикордонної служби України. 2016. - Випуск 1.

10. Уиддет С., Холлифорд С. Руководство по компетенциям / С. Уиддет, С. Холлифорд: пер. с англ. - Москва: НІРPО, 2003. - 228 с. 


\section{References}

1. Analitychnyi zvit pro vykonannia 1 - ho etapu vprovadzhennia kadrovoi komponenty $\mathrm{v}$ ramkakh proektu mizhnarodnoi tekhnichnoi dopomohy "Innovatsiinyi pidkhid do kariernoho rostu" ("INKA"); za red. H. Shroma. / H. Shrom. $\neg-$ Kyiv, 2013. - 108 s. [in Ukr].

2. Didenko O. V. Profesiina kompetentnist ofitsera-prykordonnyka: sutnist poniattia. Osvitno-naukove zabezpechennia diianisti pravookhoronnykh orhaniv i viiskovykh formuvan Ukrainy : tezy VIII Vseukrainskoi naukovo-praktychnoi konferentsii / O. V. Didenko. - Khmelnytskyi: Vyd-vo NADPSU, 2015. - 636 s. [in Ukr].

3. Orhanizatsiino-metodychni rekomendatsii shchodo orhanizatsii operatyvno-sluzhbovoi diialnosti viddilen inspektoriv prykordonnoi sluzhby : zatv. Pershym zastupnykom Holovy Derzh. prykrdon. sluzhby Ukrainy. - Kyiv, 18 sich. 2018 r. [in Ukr].

4. Raven D. Kompetentnost $\mathrm{v}$ sovremennom obshchestve. Vyiiavlenye, razvytye y realyzatsyia / D. Raven. - Moskva: Kohyto-Tsentr, 2002. - 396 s. [in Rus].

5. Robocha navchalna prohrama pidhotovky za spetsialnistiu "Molodshyi inspektor prykordonnoi sluzhby" v ramkakh proektu "Nove oblychchia kordonu". - Cherkasy, 2018. - 83 s. [in Ukr].

6. Sarafaniuk E. I. Pedahohichni umovy pidvyshchennia yakosti zahalnoviiskovoi pidhotovky kursantiv vyshchykh viiskovykh navchalnykh zakladiv $\mathrm{z}$ vykorystanniam virtualnoho modeliuvannia: avtoref. dys. na zdobuttia nauk. stupenia kand. ped. nauk: 13.00.04 / E. I. Sarafaniuk. - Odesa, 2005 - 22 s. [in $\mathrm{Ukr}$ ].

7. Sysoieva S. O., Sokolova I. V. Problemy nepereryvnoi profesiinoi osity: tezaryus naukovoho doslidzhennia / S. O. Sysoieva, I. V. Sokolova // nauk. Vydannia NAPN Ukrainy, In-t ped. osvity i osvity doroslykh, MON, Mariupolskyi derzh. Humanitarnyi un-t. - Kyiv: Vydavnychyi Dim "EKMO", 2010. - 362 s. [in Ukr].

8. Torichnyi O. V. Teoriia i praktyka formuvannia viiskovo-spetsialnoi kompetentnosti maibutnikh ofitseriv-prykordonnykiv u protsesi navchannia: monohrafiia/O O V. Torichnyi. - Khmelnytskyi: Vyd-vo NADPSU, 2012. - $536 \mathrm{~s}$. [in Ukr].

9. Torichnyi O. V. Formuvannia profesiinoi kompetentnosti maibutnikh ofitseriv-prykordonnykiv zasobamy proektnoi diialnosti / O. V. Torichnyi. - Khmelnytskyi: Visnyk Natsionalnoi akademii Derzhavnoi prykordonnoi sluzhby Ukrainy. 2016. - Vypusk 1. [in Ukr].

10. Uyddet S., Khollyford S. Rukovodstvo po kompetentsyiam / S. Uyddet, S. Khollyford: per. s anhl. Moskva: HIPPO, 2003. - 228 s. [in Rus].

Одержано статтю: 7.10.2019

Прийнято до друку: 25.10.2019

УДК 378. 147+614.212+616-092

DOI: $10.15330 /$ esu. $1.75-85$

\section{Олександра Кузенко,}

кандидат педагогічних наук, доцент, ДВНЗ “Івано-Франківський національний медичний університет" (м. Івано-Франківськ, Україна)

Olexandra Kuzenko, Candidate of pedagogical sciences $(\mathrm{PhD})$, Associate Professor, Ivano-Frankivsk National Medical University (Ivano-Frankivsk, Ukraine)

oleksandrakuz@ukr.net

\section{Ельвіра Кіндратів,}

доктор медичних наук, доцент,

ДВНЗ “Івано-Франківський національний медичний університет" (м. Івано-Франківськ, Україна)

\section{Elvira Kindrativ,}

Doctor of medical sciences, Associate Professor, Ivano-Frankivsk National Medical University (Ivano-Frankivsk, Ukraine)

kindrativ2016@gmail.com 